\title{
Study and evaluation antioxidant activity of dietary supplements with green tea extract
}

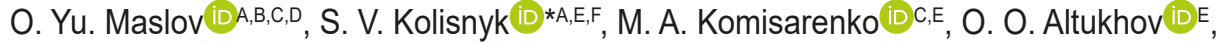 \\ K. V. Dynnyk (DE, V. I. Stepanenko DE \\ National University of Pharmacy, Kharkiv, Ukraine
}

A - research concept and design; B - collection and/or assembly of data; $\mathrm{C}$ - data analysis and interpretation; D - writing the article; $\mathrm{E}$ - critical revision of the article; F - final approval of the article

The aim of the work is to determine and evaluate the antioxidant activity of dietary supplements with green tea extract, as well as to introduce conditional terms of the level of AOA.

Materials and methods. The object of the study was dietary supplements of different manufactures: "Green Tea Extract" of Natural Sources, USA (DS1), "Extract of green tea" of Elit-Pharm, Ukraine (DS2) and "Green tea" of Pharmakom, Ukraine (DS3).

Potentiometric measurements were conducted by pH meter Hanna 2550 (Germany) with a combined platinum electrode EZDO 5010. Epigallocatechin-3-O-gallate $>98.0 \%$ (Sigma Aldrich), $\mathrm{K}_{3}\left[\mathrm{Fe}(\mathrm{CN})_{6}\right], \mathrm{K}_{4}\left[\mathrm{Fe}(\mathrm{CN})_{6}\right], \mathrm{NaHPO}_{4}, \mathrm{KH}_{2} \mathrm{PO}_{4}$ were analytical grade.

Results. It was established that a value of the antioxidant activity of DS1 was $36.51 \mathrm{mmol} / \mathrm{tab}$, DS2 - $29.78 \mathrm{mmol} / \mathrm{tab}$, and DS3 - 16.67 $\mathrm{mmol} / \mathrm{tab}$. DS1 had the highest value of the antioxidant activity, which correlated with the content of catechins $\left(\mathrm{r}^{2}=0.9314\right)$.

According to the proposed conditional terms of antioxidant activity dietary supplements, DS1 and DS2 possessed a low level of antioxidant activity, whereas DS3 corresponded to very low level of antioxidant activity.

Conclusions. It was found that the studied dietary supplements with green tea extract have antioxidant activity, which correlates with the content of catechins.

Key words: dietary supplements, green tea, antioxidant activity, potentiometry.

Current issues in pharmacy and medicine: science and practice 2021; 14 (2), 215-219

Дослідження та оцінювання антиоксидантної активності дієтичних добавок з екстрактом зеленого чаю

О. Ю. Маслов, С. В. Колісник, М. А. Комісаренко, О. О. Алтухов, К. В. Динник, В. І. Степаненко

Мета роботи - визначення та оцінювання антиоксидантної активності дієтичних добавок з екстрактом зеленого чаю, а також уведення умовних позначень рівня антиоксидантної активності.

Матеріали та методи. Об'єкт дослідження - дієтичні добавки різних виробників: «Екстракт зеленого чаю» Natural Sources, CША (ДД1), «Екстракт зеленого чаю» Еліт-Фарм, Україна (ДД2) та «Зелений чай» Фармаком, Україна (ДДЗ).

Потенціометричні вимірювання виконали на pH-метрі Hanna 2550 (ФРН) із комбінованим платиновим електродом EZDO 5010. Епіґалокатехін-3-О-галлат >98,0% (Sigma Aldrich), $\mathrm{K}_{3}\left[\mathrm{Fe}(\mathrm{CN})_{6}\right], \mathrm{K}_{4}\left[\mathrm{Fe}(\mathrm{CN})_{6}\right]$, NaHPO ${ }_{4}, \mathrm{KH}_{2} \mathrm{PO}_{4}$ мали кваліфікацію х. ч.

Результати. Встановлено, що величина антиоксидантної активності ДД1 становить 36,51 ммоль/таб., дД2 - 29,78 ммоль/таб., ДД3 - 16,67 ммоль/таб. ДД1 мав найвище значення антиоксидантної активності, що корелювало з вмістом катехінів $\left(r^{2}=0,9314\right)$.

Згідно з умовними позначеннями антиоксидантної активності, які запропонували, дієтичні добавки ДД1 і ДД2 відповідали низькому рівню, а ДДЗ - дуже низькому рівню антиоксидантної активності.

Висновки. Встановили, що досліджені дієтичні добавки з екстрактом зеленого чаю мають антиоксидантну активність, що корелює з вмістом катехінів.

Ключові слова: дієтичні добавки, зелений чай, антиоксидантна активність, потенціометричний метод.

Актуальні питання фрармацевтичної і медичної науки та практики. 2021. Т. 14, № 2(36). С. 215-219

ARTICLE

INFO

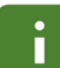

http:l/pharmed.

zsmu.edu.ualarticle view/233306
UDC 615.32:582.687.21:001.891

DOI: $10.14739 / 2409-2932.2021 .2 .233306$

Current issues in pharmacy and medicine: science and practice $2021 ; 14$ (2), 215-219

Key words: dietary supplements, green tea, antioxidant activity, potentiometry.

*E-mail: s kolesnik@nuph.edu.ua

Received: 22.04.2021 // Revised: 30.04.2021 // Accepted: 07.05.2021 


\title{
Исследование и оценка антиоксидантной активности диетических добавок с экстрактом листьев зеленого чая
}

\author{
А. Ю. Маслов, С. В. Колесник, Н. А. Комиссаренко, А. А. Алтухов, Е. В. Дынник, В. И. Степаненко
}

Цель работы - определение и оценка антиоксидантной активности диетических добавок с экстрактом зеленого чая, а также введение условных обозначений уровня антиоксидантной активности.

Материалы и методы. Объект исследования - диетические добавки различных производителей: «Экстракт зеленого чая» Natural Sources, США (ДД1), «Экстракт зеленого чая» Элит-Фарм, Украина (ДД2) и «Зеленый чай», Украина Фармаком (ДД3). Потенциометрические измерения выполнены на pH-метре Hanna 2550 (ФРГ) с комбинированным платиновым электродом EZDO 5010. Эпигаллокатехин-3-О-галлат >98,0 \% (Sigma Aldrich), $\mathrm{K}_{3}\left[\mathrm{Fe}(\mathrm{CN})_{6}\right], \mathrm{K}_{4}\left[\mathrm{Fe}(\mathrm{CN})_{6}\right], \mathrm{NaHPO}_{4}, \mathrm{KH}_{2} \mathrm{PO}_{4}$ имели квалификацию х. ч.

Результаты. Установлено, что величина антиоксидантной активности ДД1 составляет 36,51 ммоль/таб., дД2 - 29,78 ммоль/таб., ДД3 - 16,67 ммоль/таб. ДД1 имеет высокое значение антиоксидантной активности, которое коррелировало с содержанием катехинов $\left(r^{2}=0,9314\right)$. Согласно предлагаемым условным обозначениям антиоксидантной активности, диетические добавки ДД1 и ДД2 соответствовали низкому уровню антиоксидантной активности, а ДД3 -очень низкому уровню антиоксидантной активности.

Выводы. Установлено, что исследованные диетические добавки с экстрактом зеленого чая обладают антиоксидантной активностью, которая коррелирует с содержанием катехинов.

Ключевые слова: диетические добавки, зеленый чай, антиоксидантная активность, потенциометрический метод.

Актуальные вопросы фрармацевтической и медицинской науки и практики. 2021. Т. 14, № 2(36). С. 215-219

In light of the widespread degradation of environmental situation, a decrease in the content of nutrients in food, an increase in the negative impact of living in stressful conditions of a modern urban metropolis, interest in antioxidant substances that reduce the negative impact and consequences of all these processes is inexorably increasing. Antioxidants take part in the system of the defense mechanism of the human body, which main aim is combating pathologies and diseases associated with the attack of free radicals and reactive oxygen, helping to inhibit oxidative processes. The benefit of antioxidants $(\mathrm{AO})$ bases on their healing counteraction to free radicals in particular, oxidative stress in general, as well as in promoting the prevention and treatment of a number of cancers, improving human health, and increasing life [1].

More and more and more, it is possible to find in the market several new products claiming their antioxidant properties. Indeed, these are becoming an important and emerging parameter to assess the quality of the product. It has observed a high demand and interest of people on dietary supplements with green tea extract on account of their high values of antioxidant activity (AOA) [2]. Green tea has a significant high antioxidant potential owing to the presence in leaves flavon-3-ols or other name catechins [3]. These compounds differ from other polyphenols in that both carbonyl and hydroxyl groups are absent in the 4 positions. It is the most recovered of the flavonoids and therefore has the greatest antioxidant potential [4].

The major catechins in green tea are epigallocatechin-3-gallate (EGCG), epicatechin-3-gallate, epigallocatechin, and epicatechin. EGCG is the major catechin in green tea and accounts for 50-80\% representing 200-300 mg/brewed cup of green tea [5]. EGCG is with inhibitory effects in many aspects of abnormal changes, such as antioxidant, anticancer, anti-inflammatory, anticollagenase, and antifibrosis effects, appearing in its wide functional range [6]. Although, the amount of tea catechins has the highest level of AOA: it is 25-100 times higher than that of $\alpha$-tocopherol and ascorbate under comparable conditions, and epigallocatechin-3-O-gallate is one of the most powerful known plant $\mathrm{AO}$ [7].
However, today there is no regulation documents in which a universal method would be used for determining and assessing the level of AOA of test samples, such as a dietary supplement, drug, cosmetic product, alcoholic beverages. Also, there are no specific conditional terms for evaluating AOA, which does not allow to evaluate, compare the obtained values of AOA and conduct quality control of products with antioxidant property.

\section{Aim}

The aim of our study is to determine and evaluate the antioxidant activity of dietary supplements with green tea extract, as well as to introduce conditional terms of the level of AOA.

\section{Materials and methods}

The object of the study was three dietary supplements: "Green Tea Extract" (DS1), "Extract of green tea" (DS2) and "Green tea" (DS3). DS1 contains $35 \mathrm{mg}$ epigallocatechin-3-O-gallate in the form of dry standardized extract of green tea leaves, dosage form - tablets; manufacturer - "Source Naturals", USA; DS2 contains $200 \mathrm{mg}$ of dry extract of green tea leaves; dosage form - tablets; manufacturer -"Elite Farm", Ukraine; DS3 contains of dry extract (31.25 mg), ascorbic acid - $12.5 \mathrm{mg}$; dosage form - tablets; manufacturer "Pharmacom", Ukraine.

Potentiometric measurements were conducted by $\mathrm{pH}$ meter Hanna 2550 (Germany) with a combined platinum electrode EZDO 5010. Weighing was carried out using digital analytical balance AN100 (AXIS, Ukraine) with d $=0.0001 \mathrm{~g}$.

Epigallocatechin-3-O-gallate $>98.0 \%$ (Sigma Aldrich), $\mathrm{K}_{3}\left[\mathrm{Fe}(\mathrm{CN})_{6}\right], \mathrm{K}_{4}\left[\mathrm{Fe}(\mathrm{CN})_{6}\right], \mathrm{NaHPO}_{4}, \mathrm{KH}_{2} \mathrm{PO}_{4}$ were analytical grade.

The preparation solutions of dietary supplements. A crushed one tablet of each investigated dietary supplement was completely dissolved in $96 \%$ ethanol solution and filtered into a measuring flask with a capacity of $50.0 \mathrm{ml}$ and makeup to mark with the same solvent. 
The preparation standard solutions of epigallocatechin3-0-gallate. Accurately weighed $2.29 \mathrm{~g}$ of epigallocatechin-3-O-gallate was transferred into a $10 \mathrm{~mL}$ volumetric flask and dissolved in $96 \%$ ethanol solution and made up to the mark with the same solvent to give a stock solution having $0.5 \mathrm{~mol} / \mathrm{L}$ concentration. Different aliquots were taken to prepare solution with following concentrations: $0.1 \mathrm{~mol} / \mathrm{L}$, $0.01 \mathrm{~mol} / \mathrm{L}, 0.001 \mathrm{~mol} / \mathrm{L}, 0.0001 \mathrm{~mol} / \mathrm{L}, 0.00001 \mathrm{~mol} / \mathrm{L}$.

The procedure of determining the level of AOA. A $2 \mathrm{mmol} / \mathrm{L}$ solution of $\mathrm{K}_{3}\left[\mathrm{Fe}(\mathrm{CN})_{6}\right]$ was prepared by weighing $0.8232 \mathrm{~g}$ into a $25.0 \mathrm{~mL}$ volumetric flask, dissolving a compound in a distilled water, and filling the flask to volume with the same solvent. A $0.02 \mathrm{mmol} / \mathrm{L}$ of $\mathrm{K}_{4}\left[\mathrm{Fe}(\mathrm{CN})_{6}\right]$ was prepared by weighing $0.0921 \mathrm{~g}$ into a $250.0 \mathrm{~mL}$ volumetric flask, dissolving a compound in a distilled water, and filling the flask to volume with the same solvent. Then a $5.00 \mathrm{~mL}$ aliquot of both prepared solutions was taken and transferred into a $250.0 \mathrm{~mL}$ volumetric flask and made up to the mark by $0.067 \mathrm{~mol} / \mathrm{L}$ phosphate buffer solution. A $50.00 \mathrm{ml}$ of prepared mediator solution was transferred to an electrochemical cell. The initial potential of the mediator solution was measured after the initial one was established, $1.00 \mathrm{~mL}$ of the aliquot of the prepared solutions was added and a final potential was measured. The difference $(\Delta \mathrm{E})$ between the initial $\left(\mathrm{E}_{0}\right)$ and final $\left(E_{1}\right)$ potentials were found. The shift of potential was explained by the change of the ratio of oxidized and reduced forms of the mediator system as a result of the following chemical reaction:

$$
\mathrm{a} \cdot\left[\mathrm{Fe}(\mathrm{CN})_{6}\right]^{3-}+\mathrm{b} \cdot \mathrm{AO}=\mathrm{a} \cdot\left[\mathrm{Fe}(\mathrm{CN})_{6}\right]^{4-}+\mathrm{b} \cdot \mathrm{AO}_{\text {ox }}
$$

\section{(chemical reaction 1)}

where $\mathrm{AO}$ - antioxidant; $\mathrm{AO}_{\mathrm{ox}}$ - oxidized form of antioxidant; $\mathrm{a}, \mathrm{b}$ - stoichiometric coefficients.

Antioxidant activity was calculated according to the expression 1 and expressed as $\mathrm{mmol} / \mathrm{tab}$ :

$\mathrm{AOA}=\frac{\mathrm{C}_{\mathrm{ox}}-\alpha \times \mathrm{C}_{\mathrm{red}}}{1+\alpha} \times \mathrm{K}_{\mathrm{dil}} \times \mathrm{V} \times 10^{3}, \quad$ (expression 1).

In order to calculate in $\mathrm{mmol} / \mathrm{tab}$ the expression 2 was used:

$\mathrm{AOA}=\frac{\mathrm{C}_{\mathrm{ox}}-\alpha \times \mathrm{C}_{\mathrm{red}}}{1+\alpha} \times \mathrm{K}_{\mathrm{dil}} \times \mathrm{V}_{1} \times 10^{3}$, (expression 2),

where $\alpha=\mathrm{C}_{\text {ox }} / \mathrm{C}_{\text {red }} \cdot 10^{(\Delta \mathrm{E}-\text { Eethanol)nF/2.3RT }} ; \mathrm{C}_{\mathrm{ox}}$ - concentration of $\mathrm{K}_{3}\left[\mathrm{Fe}(\mathrm{CN})_{6}\right], \mathrm{mol} / \mathrm{L} ; \mathrm{C}_{\text {red }}-$ concentration of $\mathrm{K}_{4}\left[\mathrm{Fe}(\mathrm{CN})_{6}\right]$, $\mathrm{mol} / \mathrm{L} ; \mathrm{E}_{\text {ethanol }}-0.0546 \cdot \mathrm{C}_{\%}-0,0091 ; \mathrm{C}_{\%}-$ concentration of ethanol; $\Delta \mathrm{E}$ - change of potential; $\mathrm{F}=96485.333 \mathrm{Cl} / \mathrm{mol}-$ Faraday constant; $\mathrm{n}=1$ - number of electrons in electrode reaction; $\mathrm{R}=8.314 \mathrm{~J} / \mathrm{mol} \cdot \mathrm{K}$ - universal gas constant; $\mathrm{T}$ $298 \mathrm{~K}$; - coefficient of dilution, $\mathrm{V}$ - volume of measuring flask at which tablets of dietary supplements were dissolved, $\mathrm{mL}, \mathrm{V}_{1}-100, \mathrm{~mL}$.
Statistical analysis was performed in Microsoft Excel 2010 with the accepted significance level $\alpha=0.05$. Results were expressed as mean \pm confident interval from five measurements.

\section{Results}

The level of AOA ofDS1 was exceptionally high and contained $36.51 \pm 0.46 \mathrm{mmol} / \mathrm{tab}, \mathrm{DS} 2 \mathrm{had} 29.78 \pm 0.35 \mathrm{mmol} / \mathrm{tab}$, and DS3 $-16.67 \pm 0.29 \mathrm{mmol} / \mathrm{tab}$. These values were found by expression 1. In addition, the values of AOA of dietary supplements were calculated in $\mathrm{mmol} / 100 \mathrm{~mL}$ in order to classify them by offered conditional terms, in this case, expression 2 was used. As result, the DS1 had $73.02 \mathrm{mmol} / 100 \mathrm{~mL}$, DS2 - 59.56 mmol/100 mL and DS3 - $33.28 \mathrm{mmol} / 100 \mathrm{~mL}$. In our previous research [8], the total content of catechins was established by absorption spectrophotometry. It was found that the total content of catechins was $146.80 \pm 1.36$, $79.0 \pm 0.88,28.0 \pm 0.75 \mathrm{mg}$ in DS1, DS2, and DS3, respectively. The results of the study are in Table 1 .

For elaborating conditional terms, the levels of AOA of EGCG were determined for following concentrations: 0.5, $0.1,0.01,0.001,0.0001$ и $0.00001 \mathrm{~mol} / \mathrm{L}$, the results of the study are shown in Table 2.

Six conditional terms were identified: very high - more than $27322 \mathrm{mmol} / 100 \mathrm{~mL}$, high -from 5692 to $27322 \mathrm{mmol} / 100 \mathrm{~mL}$, middle - from 1423 to $5692 \mathrm{mmol} / 100 \mathrm{~mL}$, lower middle from 365 to $1423 \mathrm{mmol} / 100 \mathrm{~mL}$, low - from 45 to 365 $\mathrm{mmol} / 100 \mathrm{~mL}$, very low - from 25 to $45 \mathrm{mmol} / 100 \mathrm{~mL}$, do not possess - lower $25 \mathrm{mmol} / 100 \mathrm{~mL}$. The results of the study are in Table 3.

\section{Discussion}

According to the obtained data it easy to see that DS1 had the highest value of the antioxidant activity, second place took DS2 and last one - DS3.

For evaluation of the antioxidant potentials of the investigated dietary supplements, the potentiometric assay was applied. This method was chosen for the following reasons: firstly, it does not request expansive reagents and equipment, secondly, the method is quite sensitive, precise and fastness in comparison with other assays of evaluation AOA and moreover potentiometric method enables a prompt screening of the antioxidant capacity of a series of organic biocompounds even in complex or colored samples [9]. Although, potentiometric assay represents a single electron transfer-based method.

A simple linear regression analysis was used to investigate the correlation between the content of catechins and values of AOA. As shown in Figure 1, there was a significant positive correlation $\left(\mathrm{r}^{2}=0.9314\right)$ between the content of catechins and values of AOA.

Today, there are no uniform criteria for assessing antioxidant activity, which in turn complicates the understanding of what is good and what is bad. It is also impossible to compare the results of determining the AOA of the analyzed objects and to carry out quality control by the parameter of AOA. 
Table 1. Antioxidant activity and content of the catechins of dietary supplements

\begin{tabular}{|l|l|l|l|}
\hline Dietary supplement & AOA, mmol/tab & AOA, mmol/100 mL & Total content of catechins in dosage form, $\mathrm{mg}$ \\
\hline DS1 & $36.51 \pm 0.46$ & 73.02 & $146.80 \pm 1.36$ \\
\hline DS2 & $29.78 \pm 0.35$ & 59.56 & $79.0 \pm 0.88$ \\
\hline DS3 & $16.67 \pm 0.29$ & 33.28 & $28.0 \pm 0.75$ \\
\hline
\end{tabular}

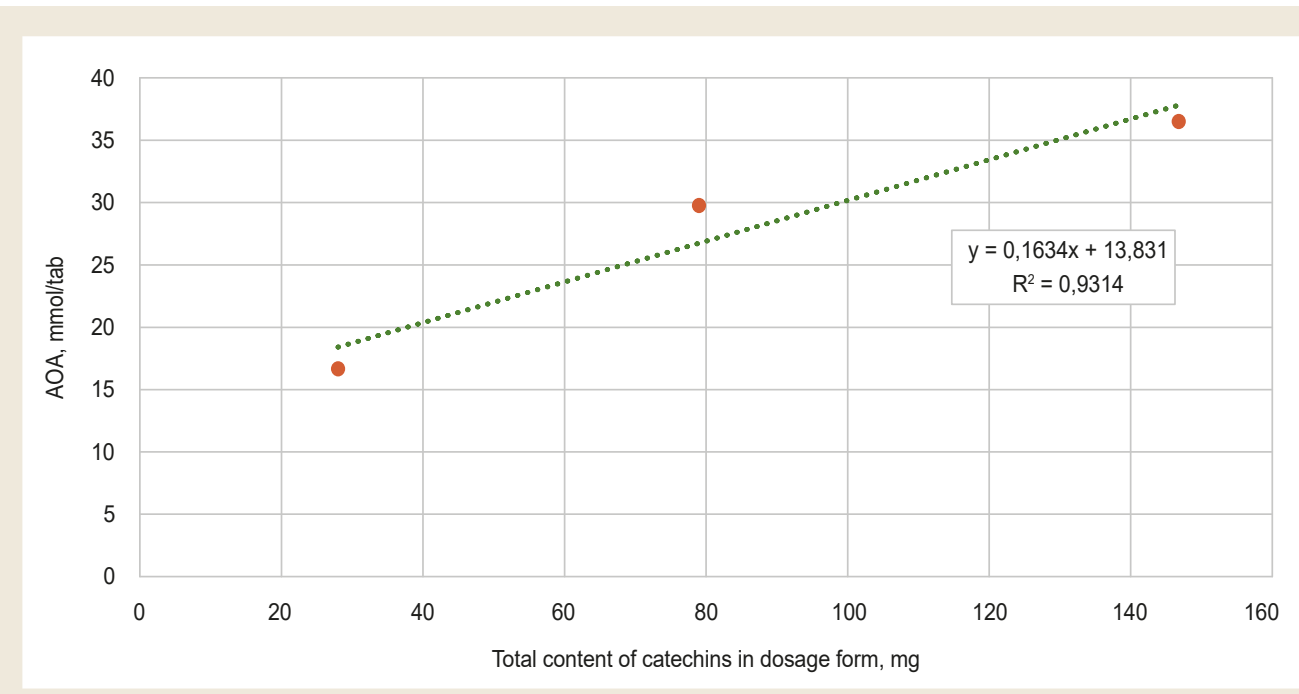

Fig. 1. The correlation between the antioxidant activity and the total content of catechins.

Table 2. Results of determination antioxidant activity of EGCG

\begin{tabular}{|l|l|} 
Concentration of EGCG, $\mathrm{mol} / \mathrm{L}$ & AOA, $\mathrm{mmol} / 100 \mathrm{ml}$ \\
\hline 0.5 & $28530.00 \pm 141.00$ \\
\hline 0.1 & $5702.00 \pm 37.66$ \\
\hline 0.01 & $1427.00 \pm 31.91$ \\
\hline 0.001 & $362.00 \pm 9.15$ \\
\hline 0.0001 & $45.00 \pm 0.85$ \\
\hline 0.00001 & $25.00 \pm 0.58$ \\
\hline
\end{tabular}

Table 3. Conditional terms of antioxidant activity

\begin{tabular}{|l|l|}
\hline Conditional term of antioxidant activity & AOA, $\mathrm{mmol} / 100 \mathrm{~mL}$ \\
\hline very high & more than 28530 \\
\hline high & from 5702 to 28530 \\
\hline middle & from 1427 to 5702 \\
\hline lower middle & from 362 to 1427 \\
\hline low & from 45 to 362 \\
\hline very low & from 25 to 45 \\
\hline do not possess & lower 25 \\
\hline
\end{tabular}

Hence, it was decided to create conditional terms denoting the AOA of the analyzed samples. Epigallocatechin-3-O-gallate was chosen as the "gold" standard for creating these conditional terms and this choice is associated with a reason that in many comparative studies to determine the value of AOA of antioxidants [10-12], EGCG had the highest ability to scavenge free radicals. According to created conditional terms of AOA, dietary supplements DS1 and DS2 possess a low AOA, whereas "Green tea" has very low AOA.

\section{Conclusions}

1. This study reported that all investigated dietary supplements with green tea extract had antioxidant activity.

2. The greatest value of antioxidant activity was found in the dietary supplement, which had the highest content of catechins.

3. The created conditional terms can be used in evaluating the antioxidant activity of products of the pharmaceutical, food, and cosmetology industries.

Prospects for further research. Introduction of regulation documents of determination antioxidant activity in products that associated with antioxidant activity and labeling information about level and conditional term of antioxidant activity.

Conflicts of interest: authors have no conflict of interest to declare. Конфлікт інтересів: відсутній.

Information about authors:

Maslov O. Yu., Assistant of the Department of Analytical Chemistry and Analytical Toxicology, National University of Pharmacy, Kharkiv, Ukraine. ORCID ID: 0000-0001-9256-0934

Kolisnyk S. V., DSc, Professor, Head of the Department of Analytical Chemistry and Analytical Toxicology, National University of Pharmacy, Kharkiv, Ukraine. ORCID ID: 0000-0002-4920-6064

Komisarenko M. A., PhD, Assistant of the Department of Pharmacognosy, National University of Pharmacy, Kharkiv, Ukraine.

ORCID ID: $\underline{0000-0002-1161-8151}$ 
Altukhov O. O., PhD, Associate Professor of the Department of Analytical Chemistry and Analytical Toxicology, National University of Pharmacy, Kharkiv, Ukraine.

ORCID ID: 0000-0002-4105-0296

Dynnyk K. V., PhD, Associate Professor of the Department of Analytical Chemistry and Analytical Toxicology, National University of Pharmacy, Kharkiv, Ukraine.

ORCID ID: 0000-0001-8483-435X

Stepanenko V. I., PhD, Associate Professor of the Department of Analytical Chemistry and Analytical Toxicology, National University of Pharmacy, Kharkiv, Ukraine.

ORCID ID: $\underline{0000-0003-1381-8015}$

Відомості про авторів:

Маслов О. Ю., асистент каф. аналітичної хімії та аналітичної токсикології, Національний фармацевтичний університет, м. Харків, Україна.

Колісник С. В., д-р фарм. наук, профессор, зав. каф. аналітичної хімії та аналітичної токсикології, Національний фармацевтичний університет, м. Харків, Україна.

Комісаренко М. А., канд. фрарм. наук, асистент каф. фрармакогнозії, Національний фрармацевтичний університет, м. Харків, Україна. Алтухов О. О., канд. фарм. наук, доцент каф. аналітичної хімії та аналітичної токсикології, Національний фармацевтичний університет, м. Харків, Україна.

Динник К. В., канд. фрарм. наук, доцент каф. аналітичної хімії та аналітичної токсикології, Національний фармацевтичний університет, м. Харків, Україна.

Степаненко В. І., канд. фрарм. наук, доцент каф. аналітичної хімії та аналітичної токсикології, Національний фармацевтичний університет, м. Харків, Україна.

\section{Сведения об авторах:}

Маслов А. Ю., ассистент каф. аналитической химии и аналитической токсикологии, Национальный фармацевтический университет,

г. Харьков, Украина.

Колесник С. В., д-р фрарм. наук, профессор, зав. каф. аналитической химии и аналитической токсикологии, Национальный фармацевтический университет, г. Харьков, Украина. Комиссаренко Н. А., канд. фрарм. наук, ассистент каф. фрармакогнозии, Национальный фрармацевтический университет, г. Харьков, Украина. Алтухов А. А., канд. фарм. наук, доцент каф. аналитической химии и аналитической токсикологии, Национальный фармацевтический университет, г. Харьков, Украина.

Дынник Е. В., канд. фрарм. наук, доцент каф. аналитической химии и аналитической токсикологии, Национальный фармацевтический университет, г. Харьков, Украина.

Степаненко В. И., канд. фрарм. наук, доцент каф. аналитической химии и аналитической токсикологии, Национальный фармацевтический университет, г. Харьков, Украина.

\section{References}

[1] Vyatkin, A. V., Pastushkova, E. V., \& Feofilaktova, O. V. (2018). Obzor metodov opredeleniya obshchei antioksidantnoi aktivnosti [The review of methods for antioxidant activity determination]. Sovremennaa nauka $i$ innovacii, (1), 58-66. [in Russian].

[2] Costa, A. S. G., Nunes, M. A., Almeida, I. M. C., Carvalho, M. R., Barroso, M. F., Alves, R. C., \& Oliveira, M. B. P. P. (2012). Teas, dietary supplements and fruit juices: A comparative study regarding antioxidant activity and bioactive compounds. LWT - Food Science and Technology, 49(2), 324-328. https://doi.org/10.1016/j.Iwt.2012.02.030

[3] Houston, N., \& Kimball, A. B. (2014). Green Tea Extract. In P. K. Farris (Ed.), Cosmeceuticals and Cosmetic Practice (Ch. 12, pp. 122-132). John Wiley \& Sons. https://doi.org/10.1002/9781118384824.ch12

[4] Katekhiny chainogo rasteniya: struktura, aktivnost', primenenie [Catechins of tea: structure, activity, application]. Biotekhnolohiia, 1(3), 25-36. [in Russian]

[5] Singh, B. N., Shankar, S., \& Srivastava, R. K. (2011). Green tea catechin, epigallocatechin-3-gallate (EGCG): mechanisms, perspectives and clinical applications. Biochemical pharmacology, 82(12), 18071821. https://doi.org/10.1016/j.bcp.2011.07.093
[6] Chu, C., Deng, J., Man, Y., \& Qu, Y. (2017). Green Tea Extracts Epigallocatechin-3-gallate for Different Treatments. BioMed research international, 2017, 5615647. https://doi.org/10.1155/2017/5615647

[7] Xu, Z., \& Howard, L. R. (2012). Analysis of antioxidant-rich phytochemicals. John Wiley \& Sons.

[8] Maslov, O. Y., Kolisnyk, S. V., Hrechana, O. V., \& Serbin, A. H. (2021). Study of the qualitative composition and quantitative content of some groups of BAS in dietary supplements with green tea leaf extract. Zaporozhye Medical Journal, 23(1), 132-137. https://doi. org/10.14739/2310-1210.2021.1.224932

[9] Pisoschi, A. M., Cimpeanu, C., \& Predoi, G. (2015). Electrochemical methods for total antioxidant capacity and its main contributors determination: A review. Open Chemistry, 13(1), 824-856. https://doi. org/10.1515/chem-2015-0099

[10] Xu, Y. Q., Gao, Y., \& Granato, D. (2021). Effects of epigallocatechin gallate, epigallocatechin and epicatechin gallate on the chemical and cell-based antioxidant activity, sensory properties, and cytotoxicity of a catechin-free model beverage. Food chemistry, 339, 128060. https:/l doi.org/10.1016/j.foodchem.2020.128060

[11] Boulmokh, Y., Belguidoum, K., Meddour, F., \& Amira-Guebailia, H. (2021). Investigation of antioxidant activity of epigallocatechin gallate and epicatechin as compared to resveratrol and ascorbic acid: experimental and theoretical insights. Structural Chemistry. https:/l doi.org/10.1007/s11224-021-01763-5

[12] Tay, P. Y., Tan, C. P., Abas, F., Yim, H. S., \& Ho, C. W. (2014). Assessment of extraction parameters on antioxidant capacity, polyphenol content, epigallocatechin gallate (EGCG), epicatechin gallate (ECG) and iriflophenone 3-C-B-glucoside of agarwood (Aquilaria crassna) young leaves. Molecules, 19(8), 12304-12319. https://doi.org/10.3390/ molecules190812304 